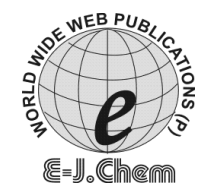

http://www.e-journals.net

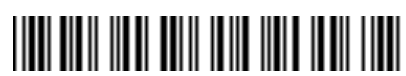

ISSN: 0973-4945; CODEN ECJHAO

E-Journal of Chemistry

Vol. 4, No. 3, pp. 354-362, July 2007

\title{
Determination of Tellurium(IV) in Various Environmental Samples with Spectrophotometry
}

\author{
P. REDDY PRASAD, J. DILIP KUMAR, B. KRISHNA PRIYA, \\ P. SUBRAHMANYAM, S. RAMANAIAH ${ }^{\#}$ and P. CHIRANJEEVI* \\ *Environmental Monitoring Laboratories, \\ Department of Chemistry, \\ "Department of Geology, \\ S. V. University, Tirupati-517502, India.
}

Received 10 December 2006; Accepted 10 February 2007

\begin{abstract}
A rapid, simple and sensitive spectrophotometer method for the determination of traces and ultra traces of tellurium(IV) were studied. These method were based on either the oxidation of leuco methylene green (LMG) to its blue form of methylene green by tellurium in acidic medium, the formed dye shows an absorption maximum at $650 \mathrm{~nm}$ in acetate buffer medium $(\mathrm{pH} 3.0$ to 5.0). Beer's law were obeyed in the concentration range $0.4-2.5 \mu \mathrm{g} \mathrm{mL}^{-1}$, having molar absorptivity and Sandal's sensitivity of $4.9 \times 10^{4} \mathrm{~L} \mathrm{~mol}^{-1} \mathrm{~cm}^{-2}$, and $0.0026 \mu \mathrm{g} \mathrm{cm}^{-2}$, respectively. The optimum reaction conditions and other analytical parameters were investigated to enhance the sensitivity of the present method. The tolerance limit of various ions with this method has been studied. The proposed method was applied for the analysis of tellurium in spiked, river, lake, spring, waste water samples, plant materials and soil samples. The results obtained by the proposed method were superior to the reported method. The performances of proposed methods were evaluated in terms of student's ' $t$ '-test and variance ratio ' $f$ '-test which indicates the significance of proposed methods over reported methods.
\end{abstract}

Keywords: Te(IV), Leuco methylene green (LMG), Spectrophotometry, Environmental samples. 


\section{Introduction}

The Tellurium and its compounds were widely used in thin films, rechargeable batteries and charge transfer systems etc. Tellurium exposure may result in garlic-like breath. The Tellurium aerosol irritates the eyes and the respiratory tract. The substance may cause effects on the liver, central nervous system, abdominal pain, constipation and vomiting. Tellurium is widely used as semiconductors and occurs in small quantities in inorganic materials and biological samples. It is also a potential environmental pollutant. Tellurium enters into natural water through seepage from soils and industrial waste. Many analytical techniques such as Voltammetry ${ }^{1}$, Flame atomic absorption spectrometry ${ }^{2}$, Atomic absorption spectrometry ${ }^{3,4}$, Inductively coupled plasma-mass spectroscopy ${ }^{5,7}$, Inductively coupled plasma-atomic emission spectroscopy ${ }^{8,9}, \quad X$-ray fluorescence ${ }^{10,11}$ and Electrophoresis ${ }^{12}$ have been employed for tellurium analysis in various environmental matrices. This increased the interest in developing rapid, sensitive and simple methods for the determination of traces of tellurium.

Several reagents have been employed for the spectrophotometric determination of tellurium in various matrices like bismuthiol ${ }^{13}, N$-phenylbenzohydroxamic acid $^{14}$, tetra methylthiourea $^{15}$, xylenol orange ${ }^{16}$, salicylfluorone ${ }^{17}$ and ion association complex such as $\mathrm{Te}^{\mathrm{IV}}-\mathrm{Cl}^{-}$- cationic violet ${ }^{18}, \mathrm{Te}^{\mathrm{IV}}-\mathrm{Br}^{-}-$butyl rhodormin-B ${ }^{19}, \mathrm{Te}^{\mathrm{IV}}-\mathrm{Br}^{-}-$acridine ${ }^{20}$, $\mathrm{Te}^{\mathrm{IV}}-\mathrm{I}^{\mathrm{I}}-$ rhodormin B-poly vinyl alcohol ${ }^{21}$ and $\mathrm{Te}^{\mathrm{IV}}-\mathrm{I}^{-}-$rhodormin B-poly vinyl alcohol $\mathrm{OP}^{22}$ systems have been used for the determination of tellurium (IV) by ion pair complex methods. The above reported methods suffer from several drawbacks such as low sensitivity, selectivity and acquire extraction ${ }^{18,20}$. The sensitivity of $\mathrm{Te}^{\mathrm{IV}}-\mathrm{I}^{-}-$rhodormin $\mathrm{B}$ poly vinyl alcohol ${ }^{21}$, $\mathrm{Te}^{\mathrm{IV}}-\mathrm{I}^{-}-$rhodormin $\mathrm{B}$ - poly vinyl alcohol $-\mathrm{OP}^{22}$ and $\mathrm{Te}^{\mathrm{IV}}$ - tungstatebasic dyes- poly vinyl alcohol ${ }^{23}$ were moderate however, the stability ion-pair complexes were very poor. So, it is desirable to develop simple, sensitive, reliable, rapid method for the determination of tellurium in various samples.

A survey of literature reveals that few spectrophotometric methods associated with ion-pair complexes were proposed for the determination tellurium in environmental samples. Here, for first time the, author's reported simple, rapid and sensitive method for the determination of traces of tellurium in various samples with oxidation process. The reaction was oxidative coupling and the product is highly stable than the methods reported in literature. The experimental variables affecting color formation and the possible tolerance of foreign ions were thoroughly studied. The optimum conditions established were incorporated in the investigation of tellurium(IV) in various environmental samples.

\section{Experimental}

\section{Instrumentation}

A Hitachi U 2001 spectrophotometer with $1.0 \mathrm{~cm}$ matched quartz cell was used for all absorption measurements. A pH meter Elico Li-129 Model glass calomel combined electrode was employed for measuring $\mathrm{pH}$ values.

\section{Reagents and solutions}

All chemicals used were of analytical reagent grade and deionised - double distilled water was used to prepare all solutions through out experiments. Working solutions of the Tellurium(IV) oxide was prepared by dilution of the corresponding standard solutions $1000 \mathrm{mg} \mathrm{L}^{-1}$ (Merck, Mumbai, India) with doubly-deionised distilled water. 1\% leuco methylene 
green (from B.D.H., Poole, UK) was prepared by dissolving $1.0 \mathrm{~g}$ of leuco methylene green in water and diluted up to the mark in a $100 \mathrm{~mL}$ standard flask with deionised - double distilled water and the solution was refrigerated.

\section{General Procedure}

Stock solution containing 1 to $100 \mu \mathrm{g}\left(0.03-3.5 \mathrm{~mL}^{-1}\right)$ of tellurium (the volume of the test solution was restricted to $1 \mathrm{~mL}$ ) were transferred into $25 \mathrm{~mL}$ calibrated flask and $5 \mathrm{~mL}$ of Leuco methylene green reagent (Scheme 1) mixture were added followed by $3 \mathrm{~mL}$ of Acetate buffer. The mixture was allowed to stand for $5 \mathrm{~min}$ for the completion of the reaction. The contents were diluted up to the mark with doubly-deionised distilled water and the absorbance was measured at $650 \mathrm{~nm}$ against the corresponding reagent blank and the calibration graph was constructed.

\section{Determination of tellurium in natural water samples}

The proposed method were employed for different natural water samples (river, lake, spring) (200 mL each) collected around Tirupati area. The samples were used directly to measure the tellurium(IV) contents by the proposed methods after filtered with cellulose membrane of pore size $0.45 \mu \mathrm{m}$ as mentioned in literature ${ }^{24}$ and determined by above general procedure.

\section{Determination of tellurium in waste water samples}

The distillation procedure for the determination of tellurium in waste water as follows: To an aliquot $(100 \mathrm{~mL})$ of known sample taken in a distillation flask, $1 \mathrm{~g}$ of $\mathrm{KBr}$ and $10 \mathrm{~mL}$ of concentrated $\mathrm{H}_{2} \mathrm{SO}_{4}$ treated with $0.5 \mathrm{~mL}$ of saturated bromine water were added and the solution was then distilled under vacuum till copious white fumes of $\mathrm{SO}_{3}$ vapours were evolved, and this process converts all other forms of tellurium in to tellurium(IV). The distillate was collected in $10 \mathrm{~mL}$ of $5 \%$ hydroxyl ammonium chloride solution, then made up to a fixed volume and analyzed by the general procedure.

\section{Determination of tellurium in vegetable samples}

$5 \mathrm{~g}$ of finely chopped fresh tomato and brinjal samples each were placed in a $500 \mathrm{~mL}$ beaker and $10 \mathrm{~mL}$ of a 1:1 (v/v) mixture of concentrated sulfuric acid and nitric acid were added. This solution was heated, until the mixture was clear. Then the solution was filtered and concentrated to $5 \mathrm{~mL}$, cooled and diluted up to $50 \mathrm{~mL}$ with doubly-deionised distilled water. The general procedure was employed to $1 \mathrm{~mL}$ of this solution for analysis of tellurium.

\section{Determination of tellurium in soil sample}

A known weight of tellurium was mixed with $20 \mathrm{~g}$ of soil sample, fused with 1:1 sodium carbonate and potassium nitrate mixture in a nickel crucible and extracted with water. The filtrate of the extract was treated with $20 \mathrm{~mL}$ of $10 \mathrm{~mol} \mathrm{~L}^{-1}$ hydrochloric acid and then heated to expel chlorine and oxides of nitrogen. The solution was further diluted with water to give a suitable concentration of tellurium. An aliquot of the stock solution was passed through the cation exchange resin (Amberlite XAD- MB-3A) to remove the iron present in soil. The tellurium contents were determined as described in the general procedure.

\section{Results and Discussion}

Absorption spectra

The absorption spectra of the leuco methylene green with tellurium show maximum absorbance at $650 \mathrm{~nm}$. Reagent blank showed negligible absorbance at this wavelength. Beer's law was obeyed over the concentration range $0.4-2.5 \mu \mathrm{g} \mathrm{mL}^{-1}$ of tellurium per $25 \mathrm{~mL}$ of the final solution at $650 \mathrm{~nm}$. The apparent molar absorptivity and Sandell's sensitivity were 
found to be $4.9 \times 10^{4} \mathrm{dm}^{3} \mathrm{~mol}^{-1} \mathrm{~cm}^{-2}$ and $0.0026 \mu \mathrm{g} \mathrm{cm}^{-2}$ respectively. Repeatability of the method was checked by the replicate analysis of the working standard solution containing $3 \mu \mathrm{g}$ per $25 \mathrm{~mL}$ of tellurium over a period of seven days and absorption spectra was shown in Figure 1.

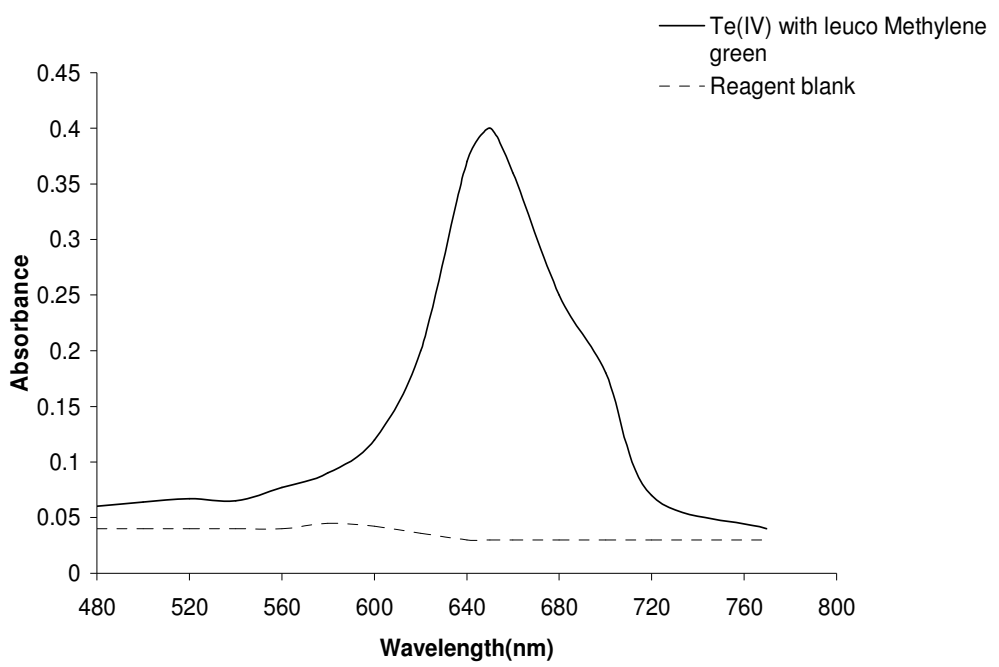

Figure 1.Absorption spectra of Te(IV) with leuco methylene green

\section{Effect of $\mathrm{pH}$ concentration}

The effect of $\mathrm{pH}$ on the peak height of tellurium(IV) at different concentrations was investigated with a fixed reagent concentration (1.0\% leuco methylene green) in the $\mathrm{pH}$ range of $3.0-5.0$ and the peak height was measured for each concentration level of tellurium(IV). At all concentration levels of Te(IV), maximum peak heights were found between $\mathrm{pH} 3.0$ - 5.0. Therefore, a $\mathrm{pH} 4.0$ was selected for further studies.

\section{Optimum conditions for color product formation}

In order to establish the optimum conditions necessary for a rapid and quantitative formation of the colored product with maximum stability and sensitivity, the investigators measured the absorbance of a series of solutions by varying one and fixing the other parameters at $650 \mathrm{~nm}$. It was found that a $1.0 \%$ solution of leuco methylene green in the range of $2.0-4.0 \mu \mathrm{g} \mathrm{mL}^{-1}$, was necessary to achieve the maximum color intensity of the oxidative coupling product. The color intensity decreased below the lower limit and above the upper limit, and a blue colored product was unstable. Therefore, $3.5 \mathrm{~mL}$ of Leuco methylene green was recommended for all measurements.

\section{Effect of temperature on colored product}

The reaction between leuco methylene green in to tellurium(IV) was found to be instantaneous. The effect of the temperature on the product was studied at different temperatures; it was found that the colored product was stable for more than 7 days in the temperature range of $25-40{ }^{\circ} \mathrm{C}$. So, the temperature of $35^{\circ} \mathrm{C}$ was selected as optimum for maximum color development.

\section{Ringbom plot for blue colored derivative}

Ringbom's plot is the established standard adopted to know the optimum range of concentration for a system that obeys Beer's law. The plot is drawn between $\log C$ of tellurium(IV) and (1-T) 
(where $T$ is the transmittance). The plot has a sigmoid shape with a linear segment at intermediate absorbance values (0.1 to 1.8$)$ and concentration values $\left(0.2\right.$ to $\left.0.2 \mu \mathrm{g} \mathrm{mL}^{-1}\right)$. The slope of Ringbom's plot from Figure 2 is 1.85 . Hence, the ratio between the relative error in concentration and photometric error is 0.2 , for a concentration of 0.2 , for $90 \%$ photometric error.

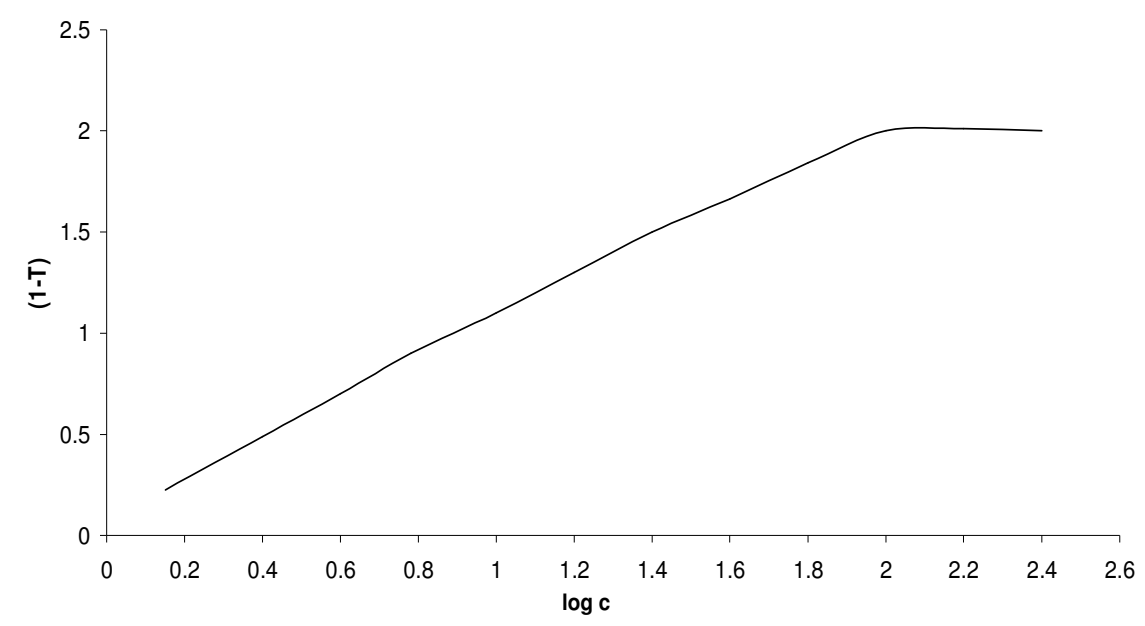

Figure.2 Ring bom's plot for Te(IV) with leuco methylene green

\section{Optical parameters}

Beer's law range, molar absorptivity, Sandell's sensitivity, and other parameters of the oxidative coupling mixture were given in (Table 1). The precision and accuracy of the method was studied by analyzing the coupling solution containing known amounts of the cited reagents within Beer's law limit. The low values of the standard deviation (\%) and the percentages of error indicated the high accuracy of the present investigation.

Table 1. Optical characteristics and precision data

\begin{tabular}{lc}
\hline \multicolumn{1}{c}{ Parameters/Characteristics } & $\begin{array}{c}\text { Leuco methylene } \\
\text { green }(\mathrm{LMG})\end{array}$ \\
\hline Color & Blue \\
$\lambda_{\text {max }}, \mathrm{nm}$ & 650 \\
Beer's law range, $\mu \mathrm{g} \mathrm{mL}^{-1}$ & $0.2-2.5$ \\
Molar absorptivity, $\mathrm{L} \mathrm{mol}^{-1} \mathrm{~cm}^{-2}$ & $4.9 \times 10^{4}$ \\
Sandell's sensitivity, $\mu \mathrm{g} \mathrm{cm}^{-2}$ & 0.0026 \\
Regression equation (Y) & \\
Slope (a) & 1.85 \\
Intercept (b) & 0.0146 \\
Correlation coefficient (r) & 0.99971 \\
Standard deviation, $\%{ }^{+}$ & 0.68 \\
Range of error $(95 \%$ confidence level) & \pm 1.2 \\
$\%$ error & 0.137 \\
\hline${ }^{*}$ Y=ax+b, where $\mathrm{x}$ is the concentration of tellurium in $\mu \mathrm{g} \mathrm{mL}^{-1},{ }^{+} \mathrm{n}=4$
\end{tabular}




\section{Reaction mechanism}

Under the reaction condition, tellurium(IV) is reduced by taking $2 \mathrm{e}^{-}$in Leuco methylene green molecule and changed into methylene green. The reaction mechanism of oxidative coupling is carried out in Scheme 1.<smiles>CN(C)c1ccc2c(c1)Sc1c(ccc(N(C)C)c1[N+](=O)[O-])N2</smiles><smiles>CN(C)c1ccc2nc3ccc(=[N+](C)C)c([N+](=O)[O-])c-3sc2c1</smiles>

Scheme 1. Oxidative coupling reaction of $\mathrm{Te}$ (IV) with leuco methylene green

\section{Interference of foreign ions}

The effect of various species on the determination of Te(IV) was investigated. The tolerance limit was taken as the amount that caused $\pm 2 \%$ absorbance error in determination of $3 \mu \mathrm{g} \mathrm{mL}^{-1}$ Leuco methylene green of tellurium. The results were shown in Table 2 .

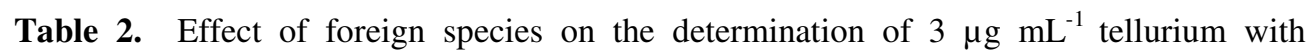
Leuco methylene green (LMG).

\begin{tabular}{lc}
\hline Species & Tolerance limit, $\mu \mathrm{g} \mathrm{mL}^{-1}$ \\
\hline EDTA & 10500 \\
$\mathrm{Na}^{+}, \mathrm{Mg}^{2+}, \mathrm{Cl}^{-}, \mathrm{NO}_{3}^{-}, \mathrm{F}^{-}, \mathrm{CHCOO}^{-}, \mathrm{CO}_{3}^{2-}, \mathrm{K}^{+}$ & 2080 \\
$\mathrm{Ba}^{2+}, \mathrm{SO}_{4}^{2-}, \mathrm{CN}^{-}, \mathrm{SCN}^{-}$, Tartarate & 1090 \\
$\mathrm{PO}_{4}^{3-}, \mathrm{Al}^{3+}, \mathrm{Cd}^{2+},{ }^{\mathrm{a}} \mathrm{NO}_{2}^{-}$ & 810 \\
${ }^{\mathrm{b}} \mathrm{Cu}^{2+}, \mathrm{Ni}^{2+\mathrm{b}}, \mathrm{Co}^{2+\mathrm{b}}, \mathrm{Ca}^{2+}$ & $86^{\mathrm{b}}$ \\
$\mathrm{Zn}^{2+}, \mathrm{Pb}^{2+\mathrm{b}}, \mathrm{SO}_{3}{ }^{2-}, \mathrm{NO}_{3}{ }^{-}, \mathrm{Cr}^{3+}, \mathrm{As}^{5+}$ & 55 \\
$\mathrm{Fe}^{2+\mathrm{a}}, \mathrm{S}^{2-}$ & 40 \\
$\mathrm{Se}^{+4 \mathrm{~b}}$ & 1000 \\
\hline
\end{tabular}

${ }^{a}$ Can be masked up to $850 \mu \mathrm{g} \mathrm{mL} \mathrm{m}^{-1}$ by the addition of $3 \mathrm{~mL}$ of $2 \%$ sulphamic acid.

${ }^{\mathrm{b}} \mathrm{Can}$ be masked up to $90 \mu \mathrm{g} \mathrm{mL}{ }^{-1}$ by the addition of $3 \mathrm{~mL}$ of $5 \%$ EDTA. 
Applications of the method for determination of tellurium(IV) and statistical comparison with reported method

The proposed methods for the determination of tellurium(IV) has been employed for real samples of water, plant materials and soil of tellurium were presented in Table 3. The obtained results were compared with the reported method ${ }^{23}$ in terms of student's ' $t$ '-test and ' $f$ '- test. The analytical data summarized in Table 3 suggest that the percentage recovery of tellurium(IV) from water, plant materials and soil ranges from 98.00 to $99.45 \%$, which is more reliable and sensitive than other methods. Analysis of tellurium(IV) in various matrices reveals the sensitivity of proposed method.

It is evident from the above data that the proposed method was simple, rapid and more sensitive than the reported methods in the literature as shown in Table 4.

Table 3. Determination of traces of tellurium(IV) in various samples.

\begin{tabular}{|c|c|c|c|c|c|c|c|c|}
\hline \multirow[b]{2}{*}{ Sample } & \multicolumn{5}{|c|}{ Proposed method } & \multicolumn{3}{|c|}{ Reported method $^{23}$} \\
\hline & 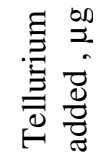 & 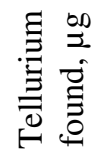 & $\begin{array}{c}\text { Recovery }^{\mathrm{a}} \\
\%\end{array}$ & $t$-test & $f$-test & 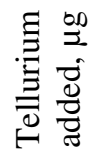 & 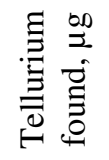 & $\begin{array}{c}\text { Recovery }^{\mathrm{a}} \\
\%\end{array}$ \\
\hline Spiked water $-\mathrm{I}^{\mathrm{b}}$ & 0.20 & 0.196 & $98.0 \pm 0.46$ & $5.05 *$ & $0.96^{*}$ & 0.20 & 0.19 & $95.0 \pm 0.46$ \\
\hline Spiked water -II ${ }^{\mathrm{b}}$ & 0.40 & 0.395 & $98.75 \pm 0.43$ & $3.03 *$ & $0.23 *$ & 0.40 & 0.39 & $97.50 \pm 0.43$ \\
\hline Waste water ${ }^{\mathrm{b}}$ & $\begin{array}{c}- \\
0.60\end{array}$ & $\begin{array}{l}0.23 \\
0.82\end{array}$ & $\begin{array}{c}- \\
98.79 \pm 0.39\end{array}$ & $5.89 *$ & $0.53 *$ & $\begin{array}{c}- \\
0.60\end{array}$ & $\begin{array}{c}0.091 \\
0.67\end{array}$ & $\stackrel{-}{96.66 \pm 0.39}$ \\
\hline River water ${ }^{\mathrm{b}}$ & $\begin{array}{c}- \\
0.80\end{array}$ & $\begin{array}{l}0.36 \\
1.14\end{array}$ & $\begin{array}{c}- \\
98.27 \pm 0.36\end{array}$ & & & - & - & - \\
\hline Lake water ${ }^{b}$ & $\begin{array}{c}- \\
1.0\end{array}$ & $\begin{array}{l}0.18 \\
1.17\end{array}$ & $\begin{array}{c}- \\
99.15 \pm 0.68\end{array}$ & & & - & - & - \\
\hline Spring water ${ }^{\mathrm{b}}$ & $\begin{array}{c}- \\
1.20\end{array}$ & $\begin{array}{l}0.08 \\
1.26\end{array}$ & $\begin{array}{c}- \\
98.33 \pm 0.23\end{array}$ & & & - & - & - \\
\hline $\begin{array}{l}\text { Plant materials } \\
\text { Tomato }\end{array}$ & $\begin{array}{c}- \\
1.40\end{array}$ & $\begin{array}{l}0.10 \\
1.49\end{array}$ & $\begin{array}{c}- \\
99.33 \pm 0.23\end{array}$ & & & - & - & - \\
\hline Brinjal & $\begin{array}{c}- \\
1.60\end{array}$ & $\begin{array}{l}\text { N.D. } \\
1.59\end{array}$ & $\begin{array}{c}- \\
99.37 \pm 0.68\end{array}$ & & & - & - & - \\
\hline Soil sample & $\begin{array}{c}- \\
1.80\end{array}$ & $\begin{array}{l}0.04 \\
1.83\end{array}$ & $\begin{array}{c}- \\
99.45 \pm 0.45\end{array}$ & $2.69 *$ & $0.95^{*}$ & - & $\begin{array}{l}0.014 \\
1.984\end{array}$ & $\begin{array}{c}- \\
98.50 \pm 0.36\end{array}$ \\
\hline
\end{tabular}

${ }^{\mathrm{a}} \mathrm{n}=4,{ }^{\mathrm{b}}$ Leuco methylene blue, N.D. = Not Detectable,

*Where $P=>0.0004$. Samples are collected from around Tirupati area. 
Table 4. Comparison of proposed methods with reported methods for spectrophotometer determination of tellurium(IV) in various samples.

\begin{tabular}{|c|c|c|c|c|}
\hline Reagents & $\underset{\mathrm{nm}}{\Lambda_{\max }}$ & $\begin{array}{c}\text { Molar } \\
\text { abosrptivity } \\
\mathrm{L} \mathrm{mol}^{-1} \mathrm{~cm}^{-1}\end{array}$ & Remarks & 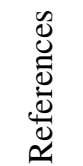 \\
\hline TMT & 382 & $2.14 \times 10^{4}$ & Less sensitive & [2] \\
\hline NPBHA & 345 & $3.5 \times 10^{4}$ & $\begin{array}{l}\text { High reagent consumption and needs } \\
\text { extraction }\end{array}$ & [1] \\
\hline $\begin{array}{l}\text { Xylenol } \\
\text { orange }\end{array}$ & 569 & $2.82 \times 10^{4}$ & $\begin{array}{l}\text { Commercial reagent, low detection limit, } \\
\mathrm{Bi}^{+3}, \mathrm{In}^{+3} \text { and } \mathrm{Ti}^{+3} \text { ions interfere seriously }\end{array}$ & [3] \\
\hline $\begin{array}{l}\text { Salicyl } \\
\text { fluorine }\end{array}$ & 534 & $1.47 \times 10^{5}$ & Interference effect is more, less selective & [4] \\
\hline $\begin{array}{l}\text { Cationic } \\
\text { violet }\end{array}$ & 590 & $4.5 \times 10^{4}$ & $\begin{array}{l}\text { More time and reagent consuming method, } \\
\text { need solvent for extraction of color species }\end{array}$ & {$[5]$} \\
\hline $\mathrm{RB}$ & 560 & $2.8 \times 10^{4}$ & Less selective, high interference effect & [9] \\
\hline Ethyl violet & 560 & $1.55 \times 10^{4}$ & Low sensitive and having less stability & [10] \\
\hline Bismuthiaol II & 330 & $3.64 \times 10^{4}$ & $\begin{array}{l}\mathrm{Hg}^{+2}, \mathrm{Se}^{+4}, \mathrm{Fe}^{3+} \text { and } \mathrm{Sb}^{3+} \text { interferes } \\
\text { seriously }\end{array}$ & [13] \\
\hline $\begin{array}{l}\mathrm{N} \text {-phenylbenzo } \\
\text { xydroxamic } \\
\text { xcid }\end{array}$ & 635 & $2.37 \times 10^{5}$ & $\begin{array}{l}\text { Needs elaborate process and benzene was } \\
\text { used for extraction }\end{array}$ & [14] \\
\hline $\mathrm{NB} / \mathrm{RB} / \mathrm{BRB}$ & $\begin{array}{l}580 / \\
565 / \\
565\end{array}$ & $\begin{array}{l}3.33 \times 10^{6} / \\
1.76 \times 10^{6} / \\
1.88 \times 10^{6}\end{array}$ & Less stability, moderate interference effect & [23] \\
\hline $\begin{array}{l}\text { Leuco } \\
\text { methylene } \\
\text { green }\end{array}$ & 650 & $4.2 \times 10^{4}$ & $\begin{array}{l}\text { Highly stable and selective, rapid, free } \\
\text { from interference effect. }\end{array}$ & $\begin{array}{l}\text { This } \\
\text { work }\end{array}$ \\
\hline
\end{tabular}

\section{Conclusions}

The proposed spectrophotometric methods for the determination of tellurium in various samples are facile, rapid and sensitive than the reported methods in literature ${ }^{23}$. These methods have added advantages over reported method ${ }^{23}$ owing to it's:

i) Coupling reagents employed in the present methods were fairly soluble in water, very cheap and readily available in market.

ii) The oxidative coupled color derivatives formed in proposed methods were quite stable when compare to reported method in the literature ${ }^{23}$, which enhances the sensitivity of the present methods.

iii) Statistical analysis of the results indicates that these methods have good precision and accuracy.

Thus the method can be adopted as an alternative to the already existing methods (ion-pair complexes). 


\section{Acknowledgements}

The authors are grateful to Head, Department of Biotechnology, S.V. University, Tirupati, for providing instrumental facility.

\section{References}

1. Locatelli C, Anal Bioanal Chem. 2005, 381(5), 1073.

2. Tokalioglu S, Kartal S and Elici L, Ann Chim. 2002, 92(11-12), 1119.

3. Grotti M, Abelmoschi M L, Soggia F and Frache R, Anal Bioanal Chem. 2003, 375(2), 242.

4. Turker A R and Baytak S, Anal Sci. 2004, 20(2), 329.

5. Lee K H, Muraoka Y, Oshima M and Motomizu S, Anal Sci.2004, 20(1), 183.

6. Lee K H, Oshima M and Motomizu S, Analyst. 2002, 127(6), 769.

7 Zhu Y, Hattori R, Fujimori E, Umemura T and Haraguchi H, Anal Sci. 2005, 21(3), 199.

8. Cariati F, Fermo P and Gilardoni S, Ann Chim. 2003, 93 (5-6), 539.

9. Xu Z, Li C, Zhang H, Ma Y and Lin S, Anal Sci. 2003, 19(12), 1625.

10. Hou X, Peters H L, Yang Z, Wagner K A, Batchelor J D, Daneel M M and Jones B T, Appl Spectrosc. 2003, 57(3), 338.

11. Takahashi A, Igarashi S, Ueki Y and Yamaguchi H, Fresenius' J Anal Chem. 2000, 36(6), 607.

12. Fung Y F and Lau K M, Electrophoresis. 2001, 22(11), 2192.

13. Toshida H, Taga M and Hikime S, Talanta. 1966, 13, 185.

14. Dasai K D and Agraval Y K, Anal. Lett. 1987, 20, 11.

15. Terpinski E A, Analyst. 1988, 113, 1473.

16. Amin A S and Zareh M N, Anal. Lett. 1996, 29, 2177.

17. Zhu Y Y, He O H and Qian J N, Lithua Jianyan Huaxue fence. 1996, $32,11$.

18. Kish P P, Balog I S, Andrukh V A and Golomb M G, Zh Anal Khim. 1990, 45, 915.

19. Skripchuk V G, Zh. Anal. Khim. 1981, 36, 1362.

20. Skripchuk V G, Chupakhim O N, Charushin V N and Ostyakaova N I, Zh. Anal. Khim, 1982, 37, 49.

21. Liu S and Liu Z, Gaodeng Хиехiao Ниахие Хиеbao. 1998, 9, 774.

22. Luo H, Mikrochim Acta. 1992, 106, 21.

23. Cao Qie, Hu Zhide, Li Zubi, Wang Jialin and Xu Qiheng, Analyst. 1998, 123, 695.

24. Suvardhan K, Suresh Kumar K, KrishnaiahL, Prabhakara Rao S and Chiranjeevi P, J Hazard Mater B. 2004, 112, 233. 


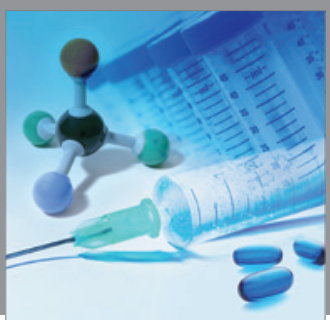

International Journal of

Medicinal Chemistry

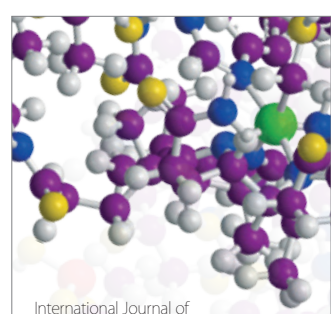

Carbohydrate Chemistry

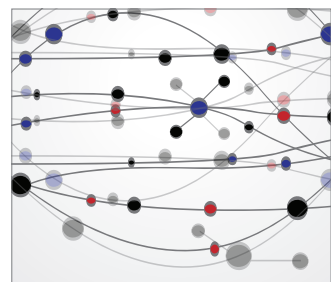

The Scientific World Journal
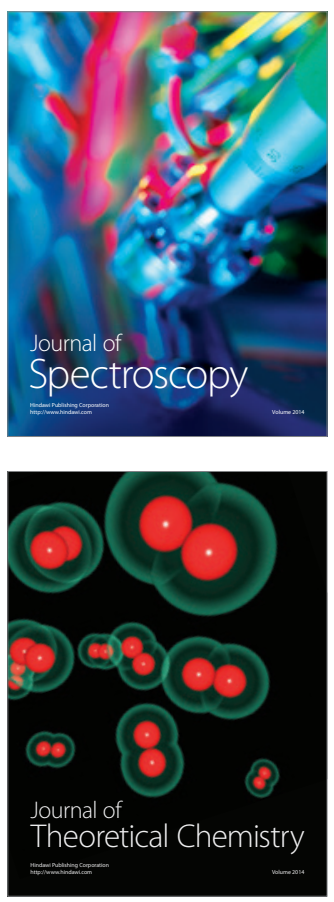
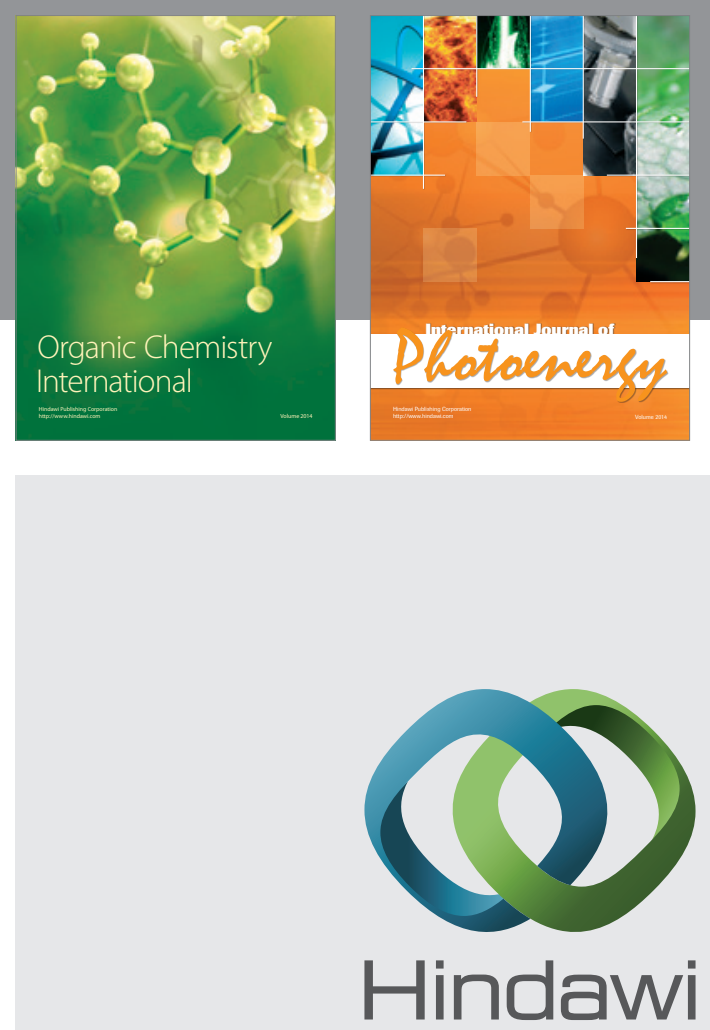

Submit your manuscripts at

http://www.hindawi.com
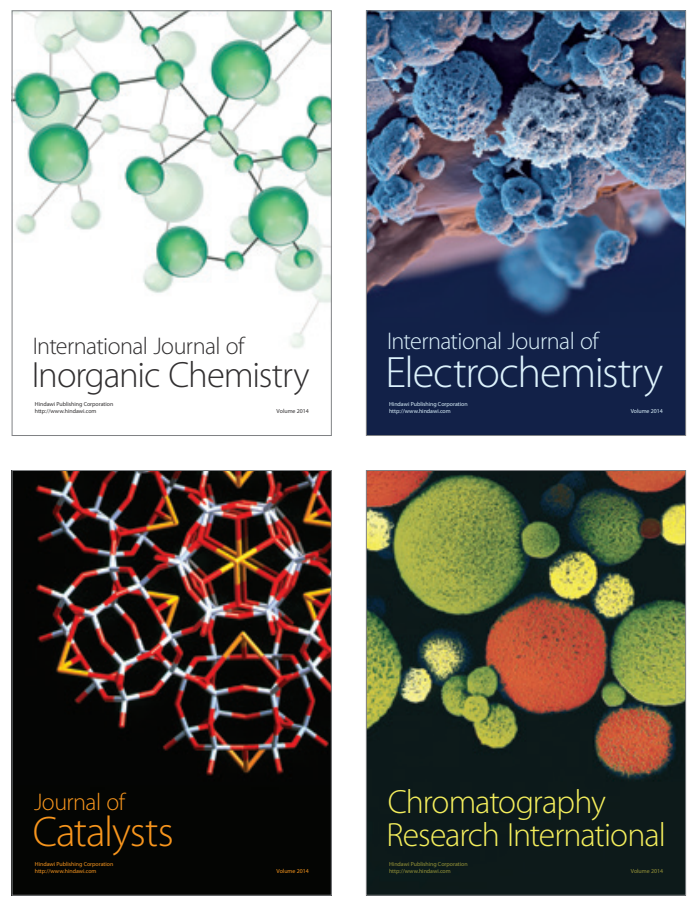
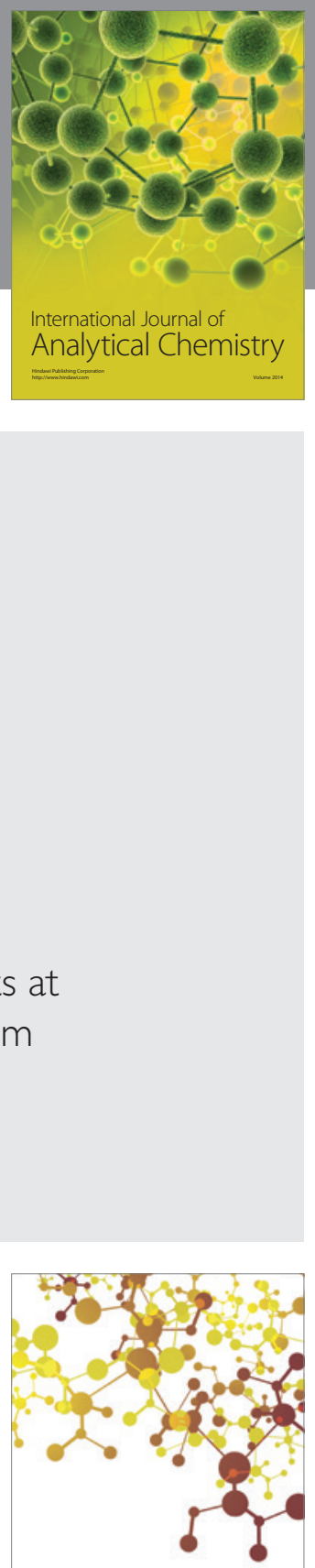

Journal of

Applied Chemistry
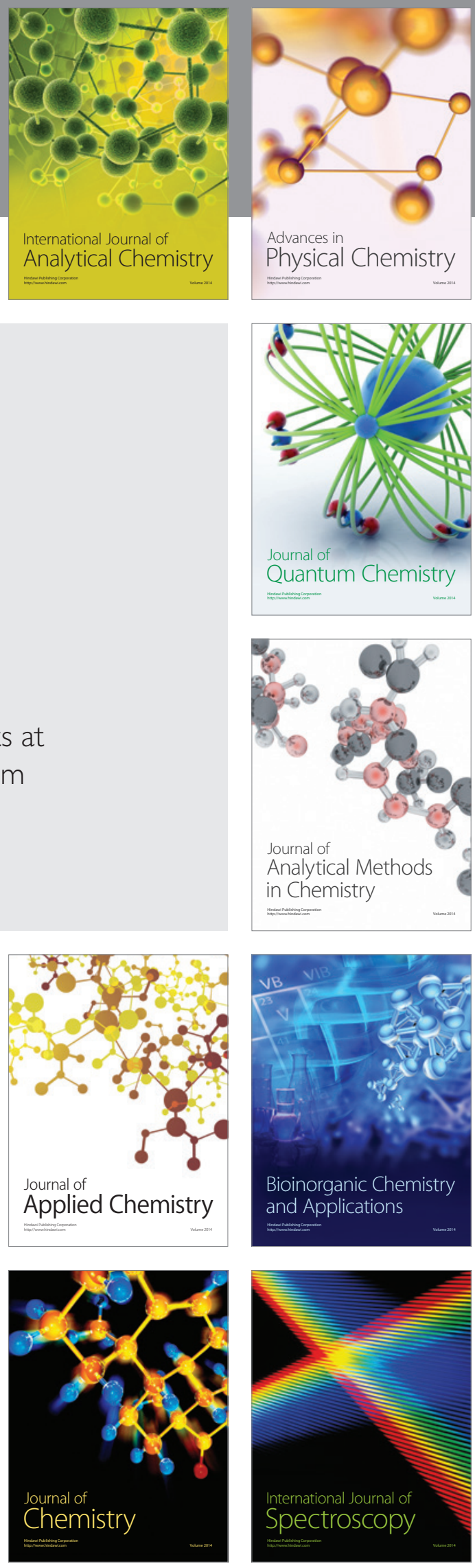